\title{
Visual Exploration of Relief of Menak Jinggo Temple for Development of Majapahit Batik Design
}

\author{
Setyawan $^{1}$ and Anung B. Studyanto ${ }^{2}$ \\ ${ }^{1}$ Department of Crafts/Textile, Faculty of Arts and Design, Sebelas Maret University, Indonesia \\ ${ }^{2}$ Department of Interior Design, Faculty of Arts and Design, Sebelas Maret University, Indonesia \\ setyawan@staff.uns.ac.id anungbs@staff.uns.ac.id
}

\begin{abstract}
This article discusses the results of the visual exploration of the Majapahit heritage in reliefs of Menak Jinggo Temple that is used as a source of visual ideas for the development of the current design of Batik Majapahit. The relief of Menak Jinggo Temple is appealing to be developed into a batik motif because of its artistic value and contains a unique visual characteristic of Majapahit style. The uniqueness of visual relief in the depictions of the Majapahit landscape and reliefs in separated panels give a complete picture of a scene that can be developed into a batik design. The design development is not only based on the visual of the past temple relief but also intertwined with creativity and the creative concept of modern designs. Specifically, this article will outline the creative process of exploring the visual of the relief of Menak Jinggo Temple into Majapahit Batik design.
\end{abstract}

Keywords: Design, Relief, Menak Jinggo Temple, Majapahit Batik.

\section{INTRODUCTION}

The Majapahit Kingdom, which developed for around two centuries (14-15 century AD), produced many relics in the form of works of art. In general, artworks produced can still be observed. The interesting part about this legacy is that Majapahit art has a distinctive artistic power that has coined the term "local wisdom" of Javanese because Majapahit art has become a milestone for the rise of Javanese art styles and original elements [1]. The art style emerged as the creative response of Majapahit artists to the cultural climate of their time, which was heavily influenced and dominated by Indian art styles [2]. One of the Majapahit heritage with unique artistic potential is the relief of the Menak Jinggo temple. The relief of this temple has the potential of artistic, iconographic, symbolic, and the uniqueness of the Majapahit visual style.

To this time, no one has specifically explored reliefs of Menak Jinggo Temple as the base of the development of new products in the form of Majapahit Batik motif designs. Majapahit Batik is made by batik artisans in Trowulan, Mojokerto, which is inspired and reprocessed from the cultural heritage of the Majapahit era in the form of visual artifacts, philosophical values, and cultural values. The inspiration is manifested in style, decoration, and batik motifs, which, as a whole, uncover the characteristics of Majapahit [3]. 
The existence of Majapahit Batik is inseparable from the historical facts of Majapahit, leaving various artifacts of art and culture, including the development of batik tradition. Batik tradition during Majapahit became a milestone in the journey of batik in Java that was not halted even after the fall of the Majapahit. Batik continued to live, spread, and grow in the trade centers of the north coast of the island of Java to Central Java. In fact, according to [4], the Mataram Kingdom, which is famous for its classic batik traditions, also inherits the Majapahit batik tradition.

The traces of Majapahit Batik can be traced from archaeological artifacts in Trowulan as it was the area of the Majapahit Kingdom. The batik traces are found on the reliefs of the Majapahit temples, such as the relief of Panji or Ramayana stories. These reliefs show the use of batik clothing and kebaya worn by women [2]. Batik, as a palace dress, has been depicted in statues of the embodiment of the king and the queen of the Majapahit kingdom [5]. The murti in Ngrimbi Temple depicts the figure of Raden Wijaya, the first king of Majapahit (ruled 12941309), wearing a cloth with a kawung motif. The motifs on the fabric were much crafted in detail lines and dots that indicate the technique used in the fabric drawing is the batik technique.

The batik traces can also be found in Serat Pararaton (Tales of Pararaton). Batik has been touted as a clothing material by mentioning the gringsing and ceplok motif as decorative batik motifs. The tale tells the event when Raden Wijaya distributed gringsing to his servants Sora, Rangga Lawe, Dangdi, and Gajah [6]. Also, news from Ma Huan, a Chinese who stopped at Majapahit in the early $15^{\text {th }}$ century, reported a beber puppet show, which is a kind of puppet show with pictures painted on a piece of bark (dlacang) or cloth as the object of his performance [7].

\section{METHOD}

Majapahit Batik has not yet developed and is not widely known by the wider community. One of the causes of this undeveloped Majapahit Batik is the lack of creativity management, such as the lack of creativity of Majapahit Batik artisans to create innovation of batik design with differentiation values and acceptable in the market. The lack of creativity is caused by the fear of Majapahit Batik artisans to explore new and more contemporary motifs that can show the history and characteristics of Majapahit Batik. Batik motifs have an essential and decisive element because the motifs will determine whether a batik has a "spirit." The motif also shows where a batik originated from [8]. It is very unfortunate because Majapahit Batik holds the tremendous potential of the artistic and cultural of the Majapahit kingdom. Majapahit heritages offer different nuances in aesthetic, iconographic, symbolic, and visual style specialties. This research discusses the opportunities for innovation in the Majapahit Batik motifs by exploring the visual of reliefs of Menak Jinggo Temple from the Majapahit era. This research will also discuss the concept of developing Majapahit Batik designs through a re-reading the historical legacy of Majapahit and exploring it into batik designs. 


\section{RESULT AND DISCUSION}

The physical form of Majapahit legacy, which can be explored as batik motifs, is the relief of Menak Jinggo Temple. The relief of this temple is depicted symbolically approaching the wayang style (two dimensions). Reliefs of Menak Jinggo temple was carved onto andesite stone. Visual relief is dominated by simple sculptures, but the sculptures provide images and purposes to be conveyed, for example, depictions of the paddy field, the nuances of the village, the nuances of the garden, and the nuances of religious.

Relief of Menak Jinggo Temple in Majapahit style gives a complete picture of Majapahit landscapes from mountains, hills, forests, paddy fields, trees (banyan, pandanus, coconut, sugar palm), place of water (lakes, ponds, rivers, sea, water sanctuaries, showers), buildings (pendopo, palaces, hermitages, temple complexes, baths), and various pictures of humans with their activities. Relief of Menak Jinggo Temple in the form of separated panels (in one frame) so it gives a complete picture of a scene that can be developed into a batik motif designs.

The artistic potential and unique visual relief of Menak Jinggo Temple open up the possibility of being explored as batik motifs. There are visual problems related to the adaptation, for instance, how to process visual relief, which is three dimensions and written into batik motif (two dimensions). This visual process brings aesthetic consequences, techniques, images, and motifs. Another problem related to motif design problems is depicting batik design by processing visual relief to maintain the uniqueness and characteristics of relief and, at the same time, reveal the visual character of batik.

The visual heritage of Majapahit, such as the relief of Menak Jinggo Temple, illustrates that during the Majapahit period, the visuals reached the peak of its development and produced not only objects of living equipment but also tools which implied expressions of high-value art [9]. The various visual works of Majapahit also give a picture of Majapahit, which is rich in visual products. The most interesting part is the visual products of Majapahit raise local elements and are more profane than the Central Javanese art, which is more Indian and leads to sacredness. The statues expressing the official beliefs of the Majapahit kingdom, the gods, took local symbols with a more individual face, and the face of gods had embodied the image of a Javanese man. Similarly, the pottery, terracotta, small statues, and relics of Majapahit offer intense local colors.

\subsection{Visual Separation}

To solve the problems, it needs to simplify the shape of the figures in the reliefs into a form of an outline without removing the old-fashioned memorable figurative style of the reliefs. The figures are in the form of buildings (houses), humans, animals (buffalo), and some types of plants such as areca nut, pandanus, as well as some plants which are not identified. For members of batik characters, the figures that have become outlines are given isen-isen (tiny motifs). Isenisen is adjusted to the character of the figure that has been processed. Building Elements in the form of buildings or places to put offerings. 
1. The Human Element is processed simply. To give the characteristic of batik on cloth, the figure is given isen-isen of cecek sawut.

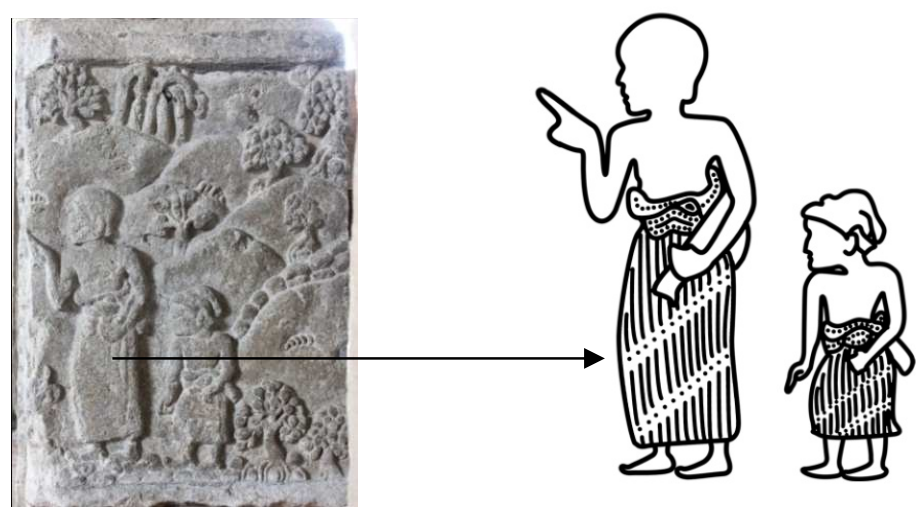

Figure 4. Reliefs of Menak Jinggo Temple (left) and Visual Exploration Results (right)

2. Flora elements

The processed element is in the form of flora, which is identified as pandanus plants. The visual plant is given isen-isen of cecek that is adjusted to the plant field. Isen-isen of cecek gives a more 'live' nuance to the visual motif.

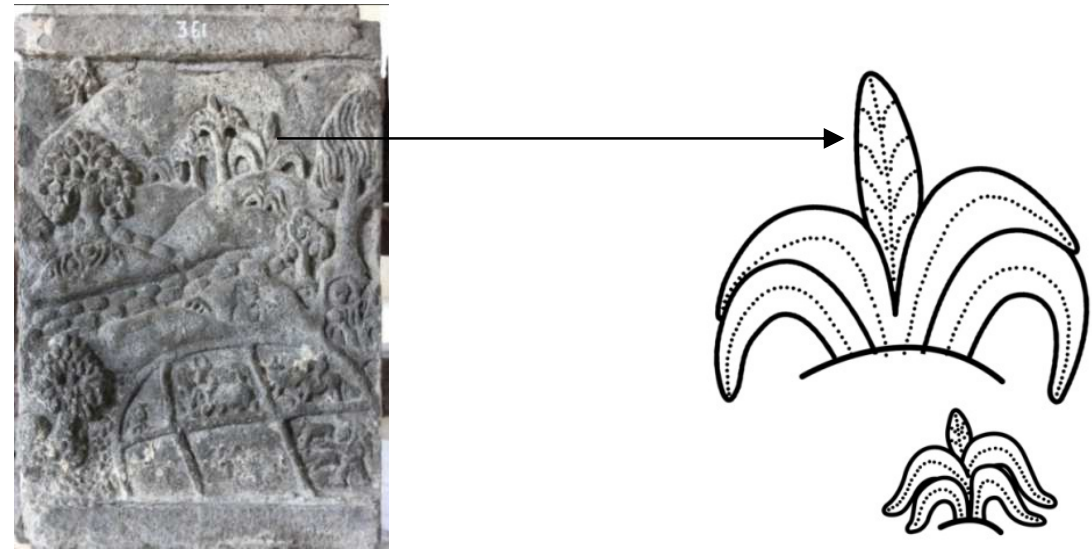

Figure 5. Reliefs of Menak Jinggo Temple (left) and Visual Exploration Results (right)

\section{Fauna Elements}

The element that is processed is fauna, which is identified as buffalo. The fauna element is deliberately not given isen-isen because the fauna element (buffalo) has a strong character. In the relief of "Menak Jingga," it only contains one element of fauna, which is buffalo as a symbol of prosperity at that time. 


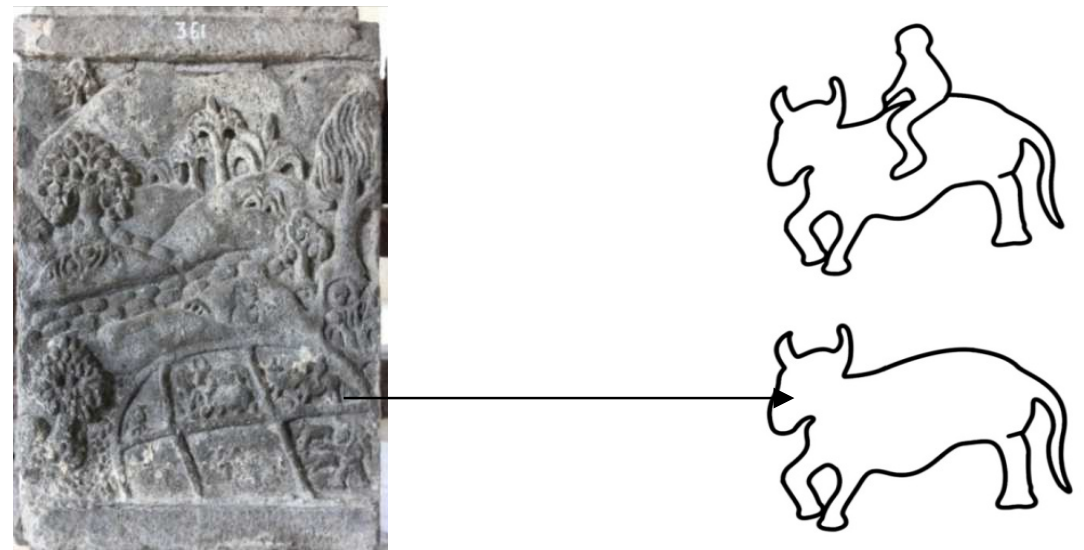

Figure 6. Reliefs of Menak Jinggo temple (left) and visual exploration results (right)

The above explorations are made by considering the batik technique that will be used to depict the design. Given that the batik technique has gone through several processes such as deepening, coloring (tying and dyeing), and wax removing process on the colored fabric, so the planned visual design considers the limitations and process of the batik. The main consideration in the development of design is that batik as pigment inhibits technique requires a inhibit media (wax) so that the colors applied to the fabric do not come out of the image or the colors do not mix with others. Besides, the pigment inhibits technique on batik cloth leaves traces on the fabric into lines that form motifs.

\subsection{Design Results}

The reliefs of Menak Jinggo Temple are developed into three design groups: (1) batik design that depicts natural landscape, (2) batik design that processes the unique visual characters of reliefs such as humans, animals, and plants, (3) batik design that incorporates natural landscapes, land contours, humans, plants, and animals that move within them into a design composition. To emerge the batik character of the three design compositions, on cloth or motifs, isen-isen is adjusted to the character of the motif image, the size of the space or field, and artistic reasons.

The development of this design attaches to the concept of the composition of the batik tradition that processes the order, repetition of motifs, and directs attention focused on the image on the surface of the cloth. The composition of tradition is maintained so that the design created is close to the character of batik. Besides, the composition of the tradition is chosen to obtain a certain rhythm to create an impression or illusion of the direction of the design created that is the impression of motion, dynamics, and will give the illusion of a view from a particular direction and angle. The composition of tradition also describes order, stability, neatness, and calmness. With the composition of tradition, the direction of developing batik designs not only displays the 
nuances of tradition but also processes contemporary visuals through the adaptation of reliefs of Menak Jinggo Temple. The result of the development of this design is the establishment of a combination of tradition and modern, established tradition with the dynamics of individual ideas that are more personal, the mixing of symbols of the past with the visual of the present[10].

Design processing by utilizing reliefs of Menak Jinggo Temple offers a different nuance, which is contemporary batik designs using outlines. The design elements are inseparable from batik elements such as the main motif, supporting motifs, and isen-isen. These elements (geometry) and non-geometry are composed of batik designs. Isen-isen is also adjusted to the main motif.

The direction of the development of this design is to open new possibilities in the creation of motifs and to break through the boundaries of traditional batik that makes Majapahit Batik stagnant or undeveloped visually. The development of design also considers the problem of batik concerning the issue of creating various opportunities, developing ideas, values, identities, practices, the direction of social change, science and technology, and the use of new media. In creating batik, it is not merely the past event, but it intertwines with the present and will give color to an ongoing process [11].
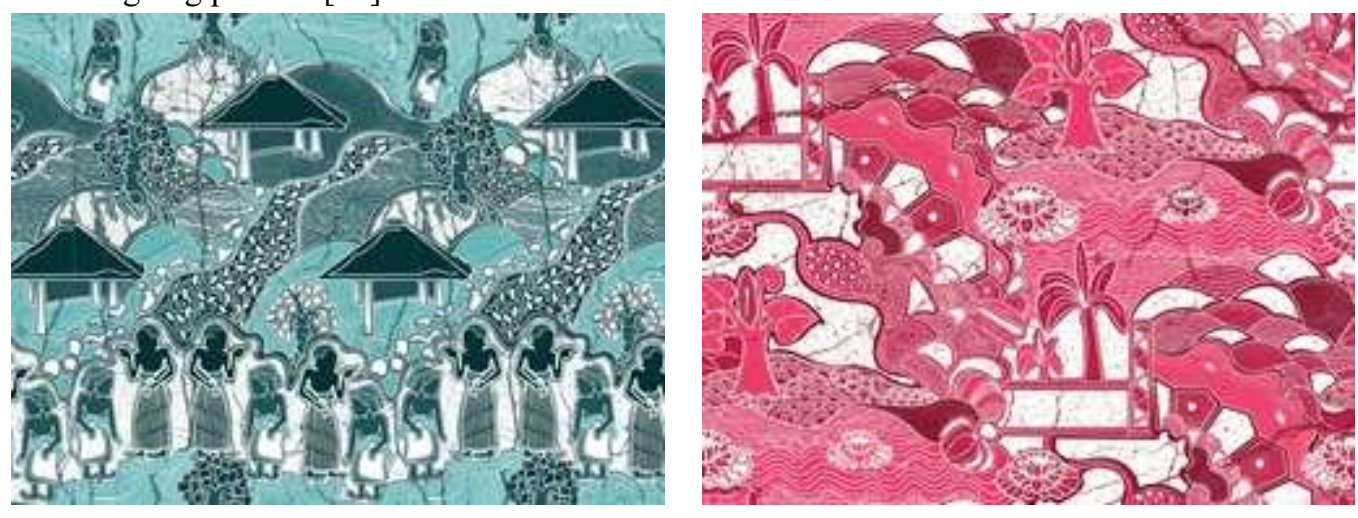

Figures 7 and 8. Majapahit Batik Design results from the visual exploration of the reliefs of Menak Jinggo Temple.

\section{CONCLUSION}

Visual exploration of the reliefs of Menak Jinggo Temple into Majapahit Batik design gives a new dimension in batik design, especially the Majapahit Batik motif. The reliefs of the Majapahit temple as a legacy of the past is brought back to be a product of the present that is undergoing renewal through a design approach. This renewal is to bridge the legacy of Majapahit with the concept and visual of the current era. This renewal concept underpins the creative process so that the batik produced is not a mere batik cloth. However, behind the batik product through the display of its motifs, it can communicate the historical values and cultural heritage of Majapahit. 
These values are represented through the appearance of motifs that have character and characteristics that will distinguish it from other regions. The visual exploration of Menak Jinggo Temple for the development of Majapahit Batik design also opens possibilities for new product development and preserves what has been passed down from the past. This exploration will maintain and, at the same time, give a new air to Majapahit Batik so it can survive in the current cultural flow. The management of this creativity can also empower Majapahit underpins artisans to be able to compete in the era of creative industries and increase revenue and shape business expansion. As it is known, batik as a home industry becomes one of the essential economic joints because it can open employment in large numbers. In this context, batik is not only the preservation effort of tradition and culture but also can be a source of economic income if it is adequately managed.

\section{REFERENCES}

[1] L. Kieven, Menelusuri Figur Bertopi Dalam Relief Candi Zaman Majapahit [Retrieving Figure with Hat in Relief of Majapahit], Jakarta: Kepustakaan Populer Gramedia dan Ecole Francaise d'Extreme-Orient (Populer Literature of Gramedia and Ecole Francaise d'Extreme-Orient], 2014.

[2] C. Holt, Melacak Jejak Perkembangan Seni Di Indonesia [Retrieving the Trace of Arts Development in Indonesia], Bandung: MSPI (Masyarakat Seni Pertunjukan Indonesia), 2000.

[3] Setyawan, "Artefak Terakota Majapahit Sebagai Sumber Ide Pengembangan Desain Batik Majapahit"[Majapahit Terracotta Artifact as the source of Majapahit Batik Design Development], Surakarta: LPPM Universitas Sebelas Maret, 2013.

[4] H.C. Veldhuisen, Batik Belanda 1840-1940; Pengaruh Belanda pada Batik dari Jawa: Sejarah dan Kisah di sekitarnya [The Influence of Dutch on Javanese Batik: History and Tales], Jakarta: Gaya Favorit Press, 1993.

[5] W. Yudoseputro, Jejak-Jejak Tradisi Bahasa Rupa Indonesia Lama [The Tradition Traces of Arts Language of Old Indonesia], Jakarta: Yayasan Seni Visual Indonesia, 2008.

[6] Hasanudin, Batik Pesisiran: Melacak Pengaruh Etos Dagang Santri pada Ragam Hias Batik [Coastal Batik: Tracing the Influence of Moeslim Scholars' Trade Ethics on Various Batik Ornaments], Bandung: PT Kiblat Buku Utama, 2001.

[7] D. Lombard, Nusa Jawa: Silang Budaya; Kajian Sejarah Terpadu Bagian II: Jaringan AsiaI [Nusa Jawa: Cross-cultural; The Study of History Part II: Asian Network], Jakarta: PT Gramedia Pustaka Utama, 1996.

[8] Y. Anshori and A. Kusrianto, Keeksotisan Batik Jawa Timur: Memahami Motif dan Keunikannya [The Ecsoticity of West Java Batik: Understanding Motifs and Its Uniqeness], Jakarta Elek Media Komputindo, 2011.

[9] E. Sri Hardiati, "Terakota Dari Situs-Situs Masa Klasik Indonesia" dalam 3000 Tahun Terakota Indonesia[Terracotta of Indonesian Classical Sites in 3000 years of Indonesian Terracotta], Jakarta: Museum Nasional Indonesia, 2000.

[10] Yunus, U., \& Tulasi, D. Batik Semiotics as a media of communication in Java. Cultura, 9(2), 143-150. 2012. 
[11] K. Saddhono, S. T. Widodo, M. T. Al-Makmun, and M. Tozu, "The study of philosophical meaning of Batik and Kimono motifs to foster collaborative creative industry," Asian Soc. Sci., vol. 10, no. 9, 2014. 